\title{
Dangerous dyads in the post-Soviet space: explaining Russia's military escalation decisions, 1992-2010
}

\author{
Paolo Rosa* (D) and Adriana Cuppuleri \\ School of International Studies, University of Trento, Trento, Italy \\ ${ }^{*}$ Corresponding author. Email: paolo.rosa@unitn.it
}

(Received 16 June 2020; revised 3 December 2020; accepted 3 December 2020; first published online 22 January 2021)

\begin{abstract}
This paper analyses the military behaviour of Russia from 1992 to 2010. The method used is a combination of the dyad analysis introduced by Stuart Bremer in 1992 and the analysis of unit-level variables, which is distinctive of foreign policy analysis. We empirically test a set of hypotheses about the determinants of Russia's military behaviour in the post-Cold War period by considering the impact of changes of international variables - relative power, the presence of military alliance pacts, the territorial salience of the dispute - and state-level variables - the degree of democracy/autocracy and regime vulnerability. A bivariate and a multivariate analysis are carried out to explain the separate and joint impacts of independent variables.
\end{abstract}

Key words: Dyad analysis; military behaviour; neoclassical realism; Russia

\section{Introduction}

The subject matter of this paper is to identify the factors that increase or decrease the likelihood of Russia's involvement in militarized interstate disputes (MIDs) in the period 1992-2010. ${ }^{1}$ According to the Correlates of War dataset, Russia was involved in 65 MIDs between 1992 and $2010 .^{2}$ Some of these disputes were with states belonging to the post-Soviet space (countries that were part of the former Soviet Union), and some of them were with states outside of this group; some of the states are great powers, and some are not; some have a defence pact with a third country, and some are not members of any alliance.

From this large mass of data, is it possible to infer the pattern of Russia's conflict decisions? To explain Russia's military behaviour, we test several hypotheses about the impact of systemic and unit-level variables. We argue that (1) Russia's military behaviour is affected by changes at the international-system level (balance of power, the territorial salience of the disputed issue, and alliance formation); and (2) the way Moscow's policy makers decide to respond to these external stimuli is influenced by domestic factors such as the nature of the political regime (level of democracy/ autocracy) and the level of social instability (the vulnerability of regime to social/political protests). ${ }^{3}$

\footnotetext{
${ }^{1}$ An MID refers to threat, display, or use of force by a state against another sovereign state (Jones et al., 1996).

${ }^{2}$ The end year of 2010 has been selected because of data availability.

${ }^{3}$ We have selected these groups of variables for two reasons. According to the literature on Russian international behaviour (see next section), the main drivers of Moscow's decisions are a combination of external changes (such as NATO intervention in Kosovo and NATO enlargement) and internal political evolution that has shifted Russia's foreign policy towards a more assertive agenda (Freire and Kanet, 2012; Donaldson et al., 2014; Tsygankov, 2018a). Considering that 'Russia sees international relations through the prism of its domestic policy and vice versa' (Roberts, 2018: 238), this paper analyses the interplay between systemic and unit-level variables.

(C) The Author(s), 2021. Published by Cambridge University Press on behalf of Società Italiana di Scienza Politica. This is an Open Access article, distributed under the terms of the Creative Commons Attribution licence (http://creativecommons.org/licenses/by/4.0/), which permits unrestricted re-use, distribution, and reproduction in any medium, provided the original work is properly cited.
} 
In the second section of the paper, we discuss the main explanations of Russia's foreign/military behaviour, highlighting their strengths and weaknesses. In the third section, the research design is detailed: the operationalization of dependent and independent variables and the formulation of hypotheses. In the fourth section, empirical data are analysed, and in the conclusion, the main findings are summarized.

The method used is an adaptation of the dyad analysis developed by Stuart Bremer to the study of a single country's foreign policy. ${ }^{4}$ We attempt to identify the dyads that include Russia that have the characteristics of increasing the risk of involvement in MIDs.

\section{International and domestic sources of Russia's military behaviour}

The very foundations of the bipolar world order collapsed in 1991 following the fall of the Soviet Union. The Cold War ended, and the newly born state of the Russian Federation faced the challenge of shaping its foreign policy afresh, taking into consideration the newly unipolar environment. As a consequence, in the last two decades, Russia has adopted various (including aggressive) foreign policy tools to implement its political agenda both globally and within the post-Soviet space. $^{5}$

Since its economic recovery in 2004, Russia has resorted to hybrid strategies and sometimes even to open conflicts with other nations, mostly with former Soviet republics. In addition to meddling in Ukraine and adding the territory of Crimea in 2014, Moscow has previously opted for a military response against Georgia in 2008. Despite its internal weakness in the 1990s, Russia intervened in several ethnic conflicts in de facto states such as Transnistria, Nagorno-Karabakh, Abkhazia, and South Ossetia (Zürcher, 2007; Ofitserov-Belskiy and Sushenstov, 2018).

In the global arena, Russia has openly intervened in the Syrian conflict since 2015 on the side of Bashar-al-Assad, supporting his regime financially and militarily. Russia's intervention has marked a sharp break from its hesitant role in the Greater Middle East after the collapse of the Soviet Union and prompted a review of its goals in the region (Casula, 2015). Following the NATO enlargement eastwards in 2004, Moscow has repeatedly expressed its concerns over the potential deployment of missile defence systems in European states near Russian borders and has warned the West about retaliatory actions if Russia's sphere of interests was not seriously taken into account (Roberts, 2018).

On the Pacific-Asian front, Russia has reinforced its Pacific fleets and strengthened its military forces close to the Chinese border, even though China has often been praised by Kremlin as one of its main economic partners in energy and weapon sales. In the same area, Russo-Japanese relations have suffered from several episodes of territorial violations regarding maritime trade routes (Kuhrt, 2018).

Russia's foreign policy and its involvement in military disputes are usually debated by means of various approaches and theories at the international, state, and individual levels of analysis (Morin and Paquin, 2018: 58).

Starting at the systemic level, the debate on explaining Russia's international behaviour is mostly framed by offensive and defensive realism. The former suggests that Russia pursues an expansionist policy as its ultimate goal by profiting from its superior relative power (Sherr, 2013). The latter sees Moscow's behaviour in terms of security needs: Russia's assertion is aimed at counterbalancing external threats (Mearsheimer, 2014; Tsygankov, 2015). Although the two arguments are presented as theoretically separate, there appears to be room for both offensive and defensive realism in the case of Russia (Götz, 2016a: 12-14). On the one hand,

\footnotetext{
${ }^{4}$ For a more in-depth elaboration on this point, see Rosa et al. (2020).

${ }^{5}$ For an overview of post-Soviet Russia's foreign policy, see Tsygankov (2018a); Götz (2016a, 2016b); Light and Cadier (2015); Donaldson et al. (2014); Freire and Kanet (2012).
} 
Russia has attempted to maximize its power and prestige with all available means, taking advantage of its economic rise (Donaldson et al., 2014). Some European countries have experienced Russia's use of energy stocks as a power leverage for interfering with their internal political issues (Oldberg, 2007; Jonsson and Seely, 2015; Siddi, 2018). On the other hand, Russia has been more likely to escalate militarily when its national interests were perceived to be under threat because of external pressure exerted by great powers, especially the EU and the USA (Asmus, 2009; Götz, 2016b). Within this framework, the Western states action in the post-Soviet space and the Middle East has been blamed as the cause triggering Russia's assertive response in Ukraine as well as in Syria (Mearsheimer, 2014).

By focusing only on external factors, structural realist approaches fail to address the variances in Russia's foreign policy. We would expect Russia to seek cooperation with Europe if defensive security and economic gain were the driving forces behind its international posture. On the contrary, we would expect conflict if Russia's final purpose were hegemony and territorial expansion (Forsberg and Haukkala, 2018). This is not always the case.

According to the state-level of analysis, Russia's involvement in military disputes is a function of domestic regime consolidation (Malcolm et al., 1996; Light and Cadier, 2015: Ch. 2; Lo, 2015). Two alternative explanations follow from this assumption. First, Russia actively resists regional democratic promotion, which poses the danger that it could spill over to Russia itself and consequently threaten the survival of Russia's regime (Ambrosio, 2009; Tolstrup, 2015). Russia has often condemned Western promotion of regime changes both at the global level and in the post-Soviet space, not only for reasons of balance of power but also because of domestic concerns (Light and Cadier, 2015: Ch. 2). ${ }^{6}$ Second, according to the theory of diversionary war, Russia uses the old tactic of diverting public attention from domestic failures by acting assertively towards other powers (Clunan, 2018). Accordingly, the recent phase of diplomatic clashes between Russia and the Western powers is related to Putin's fear of losing political consensus at home (Shevtsova, 2015).

The imperative of regime survival offers a valid argument for explaining Russia's military behaviour; however, both explanations suffer from certain limitations. First, Russia's period of conflict with the West started when economic recovery had bolstered the leadership's popularity in 2004, rather than when Putin had any problems with internal support from the end of his second mandate (Smyth, 2014). Regarding popular support, it must be clarified that there is no real sign that public discontent poses a threat to regime stability in the medium term in Russia because of a lack of real opposition (Shapovalova and Zarembo, 2011; Odinius and Kuntz, 2015). Second, the fear of democratic spill over does not explain why Russia has also opposed authoritarian regimes - for example, Kurmanbeck Bakiyev during the Tulip revolution in Kirghizstan and Aleksander Lukashenka in Belarus in 2008 - nor why Russia has close relations with Western democratic states.

Drawing on constructivism, a third group of explanations focuses on the role of ideas and culture. Accordingly, Russia's behaviour is not driven by strategic calculus but rather by identity concerns since national interests do not exist per se but may vary according to certain identity discourses (Neumann, 1995; Hopf, 2002; Tsygankov, 2013; White and Feklyunina, 2014). Scholars usually distinguish three competing identity discourses in post-Soviet Russia that influence its external relations: liberal, statist, and nationalist (Kuchins and Zevelev, 2012). ${ }^{7}$ All of

\footnotetext{
${ }^{6}$ A striking example of Russian intolerance towards Western actions in third countries is the 2007 Munich Security Conference where Vladimir Putin accused the United States of abusing power, triggering global instability and selectively applying international law after the US invasion of Iraq in 2003 and Western support of colour revolutions in post-Soviet republics. V. Putin 'Speech and the Following Discussion at the Munich Conference on Security Policy', 10 February 2007 (http://en.kremlin.ru/events/president/transcripts/24034). More recently, Russia and China have not recognized the legitimacy of the interim government in Venezuela led by the opposition leader Juan Guaidó. A. Herrero and N. MacFarquhar 'Russia Warns U.S. Not to Intervene in Venezuela as Military Backs Maduro', The New York Times, 25 January 2019.

${ }^{7}$ Scholars also use labels such as Westernist, Rationalist/Pragmatist, and Civilizationalist.
} 
them view the West as its most significant Other 'in relation to which the idea of Russia is defined' (Neumann, 1995: 1).

Closely linked to identity and power, status recognition is another important driver of Russia's international behaviour (Smith, 2014; Urnov, 2014). Russia's external actions - especially its show of force in international conflicts - would reflect the kind of recognition that Russia aims to have from other great powers (Larson and Shevchenko, 2010, 2014; Forsberg, 2014).

Finally, some scholars focus on the figure of the leader as a driving force in Russia's decisionmaking (Galeotti and Bowen, 2014; Charap and Welt, 2015; Gabuev, 2018). Due to a strong concentration of power as well as the popularity of a strong leader, the figure of the Russian president is important for addressing Moscow's foreign policy (Roberts, 2018: 237). The logical conclusion is that the state foreign policy might have been different if another individual had been in power (Jervis, 2013). ${ }^{8}$

This review reveals the necessity of considering many variables at different levels (international, domestic, and individual) for explaining Russia's international behaviour. In our research, we carried out a theoretically informed combination of different factors. ${ }^{9}$ Due to data limitations, we focused on the 1992-2010 timeframe, and we took into account only international (relative power, alliance relations, and salience of the bones of contention) and domestic (level of autocracy/democracy and regime stability) variables. Cultural and individual variables were not considered in this preliminary investigation. We are conscious that this implies a substantial simplification, but at the same time, omitting certain factors produces an empirical analysis that is easier to manage.

\section{Research design}

Our study examines to what extent Moscow's military behaviour is a function of its relative power $(R P)$, the presence or not of an external ally of the disputant state $(A l l)$, the territorial salience of the disputed issue (whether it belongs to the post-Soviet space - PSS), the level of democracy/ autocracy $(\mathrm{Pol})$, and regime vulnerability $(R V)$. The assumed directions of the relations are as follows:

- The growth of Russia's power $(R P)$ increases the probability of its involvement in MIDs.

This proposition, however, deserves some specification. The literature on conflict behaviour has produced contradictory findings: the balance of power theorists (see, e.g. Waltz, 1979) consider a balanced distribution of power as a factor that decreases the likelihood of conflictual behaviour since an equal distribution prompts mutual restraint; conversely, theorists of the preponderance of power (Kugler and Lemke, 1996; Rasler and Thompson, 2012), and supporters of the bargaining model of war (Blainey, 1988; Fearon, 1995) believe that a roughly equal distribution of power produces miscalculation, increasing the likelihood of conflicts. ${ }^{10}$ Empirical research

\footnotetext{
${ }^{8}$ On the role of individual variable, see Treisman (2012); Donaldson (2000); Bukkvoll (2016); Roxburgh (2013); Hill and Gaddy (2015).

${ }^{9}$ Although many scholars agree on the importance of addressing Russia's international behaviour through a combination of theoretical propositions, few scholars have adopted such solutions and have only focused on specific cases. They include Kuzio and D’Anieri (2018); Samokhvalov (2018); Götz and Merlen (2018), Götz (2017); Tsygankov (2013); Mouritzen and Wivel (2012: Ch. 2).

${ }^{10}$ The two opposing positions are aptly described by Bremer (1992: 313): 'Whether equality in power between states promotes war or peace has been hotly debated in the theoretical literature. Both sides make convincing arguments that appeal to common sense. One side argues that states that are radically different in power should not engage in war because the clearly weaker side would not be so foolish as to initiate or allow itself to be drawn into a war it cannot win. Hence, at the dyadic level, preponderance promotes peace. The other side of the debate argues that when two states are relatively equal in power, neither can be certain of victory, and they therefore deter one another from war. Ergo, power parity promotes peace between states'.
} 
seems to be more consistent with the latter position, even if balance of power reduces the probability of escalation once a conflict has started (Reed, 2000). Thus, our first proposition is split into two opposing theoretical expectations:

- The first affirms that the greater the power gap, the more assertive is the behaviour and the likelihood of Russia's MID involvement (balance of power theory);

- The second states that in a situation of balance, miscalculation increases the likelihood of Russia's MID involvement (preponderance of power theory).

The second proposition refers to the role of alliance in affecting the likelihood of interstate war. Despite the fact that literature on alliances is quite vast, scholars have been unable to reach a consensus whether alliances deter interstate conflicts (Fordham and Poast, 2016; Gartzke and Poast, 2018; Poast, 2019). Although some scholars argue that alliances formed to help in time of need deter the onset of militarized conflicts between contracting states, others posit that alliances are likely to cause conflict due to the logic of the security dilemma (Kenwick et al., 2015). Conversely, others have demonstrated that alliance ties reduce the likelihood of the onset of militarized conflict (Kim et al., 2019). By focusing on defensive alliance, scholars have demonstrated that the formation of such defensive pacts serve as a costly signal that provides ex ante information to potential challengers that the state target is likely to receive assistance from its allies in the event of military conflict (Leeds, 2003). Many analysts have indeed made the Article 5 from the NATO membership the key factor of deterrence against Russia's aggression, especially in the post-Soviet space (Johnson, 2015). Thus, our second proposition is:

- The lack of an external ally (All) supporting a target state will incentivize Russia's MID involvement.

The third proposition is derived by the territory-centred (or issue-centred) approach to studying causes of war and dynamics of conflict. Within this approach, some scholars have contributed to the findings on contiguity and war onset by explaining that wars are not only concentrated among neighbours because contiguity provides an opportunity to war, but also (and above all) because territoriality, under the right circumstance, provides a motivation for war. Others scholars have considered the character of the dispute, namely the issue states fight over, as determinative of state action over territorial disputes. In particular, issues that are seen by decision makers as more 'salient', or important, are expected to be more likely to lead to militarized conflicts and harder to resolve to both sides' satisfaction. In the case of Moscow's military behaviour, it has been widely written about the significance - whether material or iconic - that the post-Soviet space represents to Russia's national interest. ${ }^{11}$ The third proposition is:

- A high territorial salience of the dispute (in or out of the PSS) will incentivize Russia's MID involvement.

The fourth proposition looks at domestic political dimensions - in particular, the regime type - as the main driver of a state foreign policy:

- A low level of democracy $(\mathrm{Pol})$ will incentivize Russia's MID involvement.

\footnotetext{
${ }^{11}$ On territory and international politics, see Bremer (1992); Frederick et al. (2017); Hensel et al. (2008); Hensel (2012); Fravel (2008/2009); Huth (1996); Diehl (1991); Senese (2005); and Vasquez (1995). On the role of territorial issues in Russian foreign policy, see Ortman (2018); Toal (2017); Trenin (2009); Rytövuori-Apunen (2019).
} 
This proposition derives from the democratic peace theory, whose main argument is that democracies are less war prone than other regimes (at least vis-à-vis other democracies). ${ }^{12}$ Conversely, less democratic regimes are more inclined to get involved in military conflicts. Although the causal logic that underpins democratic peace theory has been critically discussed, ${ }^{13}$ the argument has been used to address Russia's foreign policy. In particular, some scholars not only point at the authoritarian nature of the Russian regime as the main source of Moscow's assertive foreign policy but also holds that Russia's relations with the post-Soviet space is affected by Russia's fear of democratic contagion. ${ }^{14}$

Finally, the fifth proposition derives from the diversionary theory of war according to which, leaders use force abroad in order to divert public's attention from domestic failure or to increase their domestic political support:

- A high/low level of the regime vulnerability $(R V)$ will incentivize Russia's assertive military behaviour. In this case, we have to formulate two opposing propositions due to the lack of a strong consensus in the literature on the link between Russia's international behaviour and domestic turmoil.

By fomenting the idea of an external enemy by means of extensive state-led media campaigns, the Kremlin manages to motivate and unify its population through what is usually known as the 'rally around the flag' effect (Filippov, 2009).

\section{Dependent variable}

Our dependent variable is Moscow's involvement in a military dispute. It is operationalized using the Correlates of War (COW) data on nations' involvement in an MID (Jones et al., 1996). ${ }^{15}$

To identify the best predictors of Moscow's MID involvement, all the possible dyads that included Russia in the period 1992-2010 were considered $(N=3591),{ }^{16}$ and the characteristics of the more conflict-prone dyads were analysed. A total of 62 MIDs out of 65 were analysed. Three were omitted for several reasons: MID no. 3563 was omitted because data were missing both in the MID narrative file and in the MIDLoc dataset, and MIDs no. 4186 and 4343 were omitted because no Russian involvement was mentioned in the MID narrative file. MID nos. 4197 and 4411 were split into two (Russia/USA and Russia/Canada; Russia/Georgia and Russia/Azerbaijan). MID no. 4342 that involved a dispute between Russia and NATO was split into 19 MID per year. ${ }^{17}$ Thus, the final number of MIDs included in the sample was 82 .

\section{Independent variable}

The first systemic independent variable is relative power $(R P)$. It was operationalized using the COW's Comprehensive Index of National Capabilities (CINC). As stated before, power distribution can be linked in different ways to conflictual behaviour, producing two alternative hypotheses about war-proneness:

\footnotetext{
${ }^{12}$ On the dyadic democratic peace theory, see Maoz and Russett (1993); Russett (1993); and Oneal and Russett (1999). On the monadic democratic peace theory, see Quackenbush and Rudy (2009).

${ }^{13} \mathrm{See}$, in particular, studies on the warlike effects of 'process of democratization' (compared to consolidated democracy) (Mansfield and Snyder, 1996; McFaul, 1997/98; Rosato, 2003).

${ }^{14}$ Boris Barkanov, 'How Putin's Domestic Audience Explains Russia’s Behavior', Washington Post, 13 March 2014.

${ }^{15}$ Involvement in an MID is a standard indicator used in the literature on quantitative analysis of conflicts (McLaughlin Mitchell and Vasquez, 2014).

${ }^{16}$ Our unit of analysis is the 'nation in a dyad per year': we consider all potential dyads that include the observed state.

${ }^{17}$ For this solution, see Bremer (1992: 320-321); and Jones et al. (1996: 174-175).
} 
Hypothesis 1a: Under condition of large difference in relative power $(R P)$ (number of dyads in which the ratio of Russia and opponent's $R P$ is $>10),{ }^{18}$ Russia's likelihood of MID involvement increases.

Hypothesis 1b: Under condition of small difference in relative power $(R P)$ (number of dyads in which the ratio of Russia's and opponent's RP is equal to or less than 3), Russia's likelihood of MID involvement increases.

The second systemic variable is alliance relation $(A l l)$. It was operationalized using a dummy variable (yes/not). To trace the formal alliance relations of Russia's opponents, the COW dataset on alliances was used. We considered all the dyads in which Russia was involved that included a disputant state with a defence pact with a third country. ${ }^{19}$ Thus, the second hypothesis is the following:

Hypothesis 2: If the target state has no alliance relations (number of dyads in which Russia interacts with a state without a formal defence pact with a third country or with an alliance not including Russia itself), ${ }^{20}$ Russia's likelihood of MID involvement increases.

The third systemic variable is territorial salience, which was operationalized in an approximate way. We used a dummy variable (yes/not), distinguishing between dyads including or not including countries belonging to the post-Soviet space. ${ }^{21}$ The reason for this choice is that the post-Soviet space plays a pivotal role in Russia's foreign policy for several strategic and ideational reasons. First, since the mid-1990s, Russia has aspired to become a self-standing power with a global reach (Trenin, 2009). Consequently, former Soviet borderlands are considered part of the regional hegemony as well as a buffer zone for balancing behaviours against external threats (Costa Buranelli, 2017). Second, the post-Soviet space has inherited a large part of the transport infrastructure and military installations built during the Soviet Union and the Tsarist empire. Access to these infrastructures remains of vital interest to Russia. Third, there are more than 25 million ethnic Russians living beyond Russian borders. This large community has been mobilized by Kremlin either for opposing anti-Russian decisions in post-Soviet republics - for example, the 'Bronze soldier' affair in Estonia - or as pretext for intervening militarily in defence of 'compatriots abroad' (Casula, 2014). Finally, because of its imperial legacy, the post-Soviet space represents a key zone for identity construction of post-Soviet Russia as a unique civilization that is both Orthodox and Eurasian. Such civilizational stance has been functional to Russia's projection of its soft power within and beyond the post-Soviet space as it provides interpretive elasticity that accommodates geopolitical, nationalist, religious, anti-globalist, and anti-Western ideas (Tsygankov, 2013; Laruelle, 2015). Thus, the third hypothesis is as follows:

Hypothesis 3: In post-Soviet space (PSS) (number of dyads in which Russia interacts with states belonging to the post-Soviet space), Russia's military behaviour will be more assertive, with an increased probability of MID involvement. ${ }^{22}$

\footnotetext{
${ }^{18} \mathrm{~A}$ large power difference is when the ratio between the RP of the most powerful state and the less powerful one is greater than 10; a small power difference is when the ratio between the RP of the most powerful state and the less powerful is equal or less than 3; a medium power difference is when the ratio between the RP of the most powerful state and the less powerful state is between 3 and 10. For an explanation of these thresholds, see Bremer (1992: 322-323).

${ }^{19}$ Cow's alliance dataset considers four types of formal alliances: neutrality, entente, non-aggression, and defence pact (Gibler, 2009). We have considered only alliances that included a defence pact.

${ }^{20}$ We have not considered the collective defence pacts of 1992 and 1995 that include all the post-Soviet space countries. The rationale for this choice is that we consider only pacts that follow the logic of external balancing against Russia itself.

${ }^{21}$ For a more sophisticated theorization of territorial salience, see Hensel et al. (2008), Hensel (2012).

${ }^{22}$ The post-Soviet Space (PSS) includes: Russia, Armenia, Azerbaijan, Belarus, Estonia, Georgia, Kazakhstan, Kyrgyzstan, Latvia, Lithuania, Moldova, Tajikistan, Turkmenistan, Ukraine, and Uzbekistan.
} 
The two domestic variables considered are the nature of the political regime $(P o l)$ and its vulnerability $(R V)$. The first variable refers to the level of democracy/autocracy of the political institutions. The second variable refers to internal threats to the survival of political regimes.

In the case of Russia, unit-level variables such as elite instability - that can be useful to measure the capacity of a state to formulate an assertive foreign policy (Schweller, 2004) - are meaningless because Russia has experienced few non-institutional changes in government in the period considered (Gel'man, 2015). An alternative is to measure the level of democracy/autocracy of the regime (Mansfield and Snyder, 1996; Macfaul, 1997/98; Lynch, 2011). We split analysis into two parts. First, we tested a hypothesis derived from the literature on Russia's foreign policy that states that Moscow is assertive because it is authoritarian and afraid of democratic contagion. The consequent conclusion is that if Russia were a more democratic and liberal country, it would behave differently. Thus, our first hypothesis is that a decrease or an increase in the level of democracy in Russia (regardless of the nature of the opposing state's political regime) should be associated with more or less aggressive military behaviour. To measure this variable, we used the Polity IV dataset and analysed the effect of an increase or a decrease of one standard deviation over/below the average score of the democracy index of Russia on its international behaviour. Second, looking more to the literature on democratic peace (Maoz and Russett, 1993; Russett, 1993; Oneal and Russett, 1999), we considered all the democratic, mixed, and non-democratic dyads in which Russia is involved to see whether - when Russia and the opponent are both democracies - the risk of escalation is lower. Thus, our operational hypotheses regarding regime characteristics are as follows:

Hypothesis 4a: Under the condition of declining democracy (number of dyads in which Russia's Pol1 score is one standard deviation below the average), Russia's military behaviour will be more assertive, with an increased probability of MID involvement. ${ }^{23}$

Hypothesis 4b: In a situation of non-democratic or mixed dyads (the number of dyads in which both Russia and the opponent's Pol 2 score is less than 6 or the score of at least one member of the dyad is less than 6), Russia's military behaviour will be more assertive, with an increased probability of MID involvement.

The second domestic variable is regime vulnerability $(R V)$. This variable refers to the risk of a violent overthrow of a government because of intense social instability and includes the broad literature on the diversionary theory of war. Some studies show that regime vulnerability is positively associated with external assertive behaviour (diversionary war), while others show that regime instability produces a low-profile foreign policy (Hagan, 1993; Levy, 2001; Mclaughlin Mitchell and Prins, 2004).

In the case of Russia, the literature states that Russia is more assertive when internal consensus is declining (Cohen, 2007; Filippov, 2009; Clunan, 2018). On the contrary, some scholars point to the low political consensus and weak state capacity as the sources of Russia's low-profile foreign policy in the early 1990s (Götz, 2017: 9-12).

To calculate the RV's value, the misery index (inflation rate plus unemployment rate) is used as a proxy. ${ }^{24}$ The sample was divided into three tertiles (low, medium, and high). A situation considered highly unstable has an $R V$ score in the third tertile, and a situation of low vulnerability has an $R V$ score in the first tertile. Accordingly, our hypotheses (to test both the low-profile foreign policy theory and the diversionary theory) are as follows:

\footnotetext{
${ }^{23}$ The average score of the Pol1 index for Russia is 4.4, the standard deviation is 1.3 .

${ }^{24}$ For the different indicators used to measure social instability in the diversionary war literature, see DeRouen (1995), and Maclaughlin Mitchell and Prins (2004). The misery index used in this paper, as Karl DeRouen puts it, can be considered 'as a representation of the state of the national economy' (DeRouen, 1995: 681).
} 
Hypothesis 5a: In a situation of low regime vulnerability (number of dyads with Russia showing an $R V$ score in the first tertile), Russia's likelihood of MID involvement increases (low-profile foreign policy theory).

Hypothesis 5b: In a situation of high regime vulnerability (number of dyads with Russia showing an $R V$ score in the third tertile), Russia's likelihood of MID involvement increases (diversionary war theory).

The analysis was first conducted in a bivariate form, comparing unconditional and conditional probabilities, and then a multivariate analysis was run to measure the joint effect of all independent variables.

\section{Data analysis}

The results of our research are presented in Tables 1 and 2. Table 1 presents the results of the bivariate analysis, and Table 2 presents the results of the multivariate analysis.

As is clearly evident from the figures in Table 1, the main results are mostly consistent with our hypotheses. Nevertheless, hypotheses are derived from theories of international relations that are partly complementary and partly competitive. Therefore, although international variables operate with one significant exception, domestic variables necessitate some qualifications.

The role of relative power $(R P)$ is very important for explaining the risk of Russia's involvement in a military dispute. The probability of a military escalation largely increases when the power difference is small and decreases when it is large. When the power difference is small, there is an increase in the probability of military escalation from 0.023 (unconditional probability $-p_{\mathrm{u}}$ ) to 0.103 (conditional probability $-p_{c}$ ); in other words, when the power difference between Russia and the other states is less than 3, the likelihood of Moscow's military involvement increases almost five times. This result is highly statistically significant ( $Z$ score: $7.45, p<0.001$ ). Conversely, when the power difference is very large (Russia's power is more than 10 times as great as its adversary), the probability of a military dispute decreases sharply. In this situation, the probability of Russia's MID involvement shifts from 0.023 to 0.015 , with a significant decline in risk $(Z$ score: $-2.94, p<0.01)$.

Considering the role of power, the results of our analysis seem consistent with hypothesis $1 \mathrm{~b}$, which affirms that a conflict is more likely when there is not such a great power gap between the contending states: in this case, mutual miscalculation about the outcome of a conflict drives both states to decide not to back down. The idea that a balanced distribution of power is a source of peace is not confirmed by Russia's military behaviour. As the rationalist theory of war states, Moscow's risk of military escalation increases dramatically when the adversaries are not so weak as to decide to capitulate without fighting. As Geoffrey Blainey put it (1988: 114): 'Indeed one can almost suggest that war is usually the outcome of a diplomatic crisis which cannot be solved because both sides have conflicting estimates of their bargaining power'. This is not the case when there is a situation of preponderance and Russian leaders are no exception.

The second international variable linked to power distribution - alliance $(A L L)$ - does not work as well as $R P$. It works in the opposite direction vis-a-vis our expectations and has no statistical significance. Our hypothesis (hypothesis 2) was that - adhering to a logic of external balancing - the presence of a defence pact with a third country by the target state would deter Moscow's military intervention or at least reduce its frequency. The data are not consistent with this expectation. The direction of the relation is positive, which means that Russia's likelihood of MID involvement is greater with countries that have a defence pact with a third country and not the other way around. This can be explained in three ways:

(1) External balancing is not considered credible by Moscow's decision makers;

(2) The result is produced by a selection bias, that is, states that have good reasons to be involved in a dispute with Russia are more motivated to enter into an alliance system; 
Table 1. Conditional probabilities of Russia's involvement in militarized disputes, 1992-2010

\begin{tabular}{|c|c|c|c|c|}
\hline & MID (exp. MID) & Russia/Dyad & $\operatorname{pr}(\mathrm{MID})^{\mathrm{a}}$ & $Z$ score \\
\hline & & Population & & \\
\hline & 82 & 3591 & 22.8 & \\
\hline & & Relative power (RP) & & \\
\hline Large difference & $43(67.0)$ & 2922 & 14.7 & $-2.94^{\star \star}$ \\
\hline Medium difference & $19(10.8)$ & 474 & 40.1 & $2.51^{\star}$ \\
\hline \multirow[t]{2}{*}{ Small difference } & $20(4.2)$ & 195 & 102.6 & $7.45^{\star \star \star}$ \\
\hline & & Alliance (All) & & \\
\hline Yes & $48(46.1)$ & 2025 & 23.7 & 0.26 \\
\hline \multirow[t]{2}{*}{ No } & $34(35.9)$ & 1566 & 21.7 & -0.30 \\
\hline & & Post-soviet space (PSS) & & \\
\hline Yes & $24(6.1)$ & 266 & 90.2 & $7.36^{\star \star \star}$ \\
\hline \multirow[t]{2}{*}{ No } & $58(75.9)$ & 3325 & 17.4 & $-2.08^{\star}$ \\
\hline & & Polity (Pol1) & & \\
\hline High & $23(30.5)$ & 1336 & 17.2 & -1.37 \\
\hline Medium & $11(21.7)$ & 951 & 11.6 & $-2.33^{\star}$ \\
\hline \multirow[t]{2}{*}{ Low } & $48(29.8)$ & 1304 & 36.8 & $3.38^{\star \star \star}$ \\
\hline & & Polity (Pol2) & & \\
\hline Democratic dyads & $16(13.8)$ & 605 & 26.5 & 0.60 \\
\hline Mixed dyads & $48(34.3)$ & 1502 & 32.0 & $2.37^{\star}$ \\
\hline Non-democratic dyads & $16(21.5)$ & 941 & 17.0 & -1.20 \\
\hline \multirow[t]{2}{*}{ Missing $^{\mathrm{b}}$} & 2 & 543 & & \\
\hline & & Regime vulnerability (RV) & & \\
\hline High & $44(25.4)$ & 1112 & 39.6 & $3.74^{\star \star \star}$ \\
\hline Medium & $28(30.3)$ & 1327 & 21.1 & -0.42 \\
\hline Low & $10(26.3)$ & 1152 & 8.68 & $-3.22^{\star \star}$ \\
\hline
\end{tabular}

${ }^{*} P<0.05 ;{ }^{*} P<0.01 ;{ }^{* \star *} P<0.001$ (two-tailed test).

${ }^{\mathrm{a}}$ To facilitate reading, probabilities have been multiplied by 1000 .

'The Polity IV project does not code countries with less than 500,000 inhabitants; cases of foreign 'interruption' are treated as missing.

(3) Russia is more conflict prone with states that have an alliance because it wants to prevent the formation of future alliances, making them not worth the risk.

In any case, the All variable is not statistically significant in the bivariate analysis; thus, we can say that Russia's military decisions do not seem very affected by this dimension of power distribution. ${ }^{25}$

The third international variable considered is the territorial salience of the dispute. We coded this variable in a very simple way: whether the disputant state belongs or does not belong to the post-Soviet space (PSS). PSS, together with $R P$, is the best predictor of Russia's military behaviour. The probability of Russia's MID involvement shifts from a $p_{\mathrm{u}}$ of 0.023 to a $p_{\mathrm{c}}$ of 0.090 when we consider only dyads including states that belong to the PSS. This means a risk of conflict four times greater. The result is highly statistically significant ( $Z$ score: 7.36 , $p<0.001)$. These figures are consistent with our hypothesis 3 . Although the factor of geographic proximity can be deemed as a 'structural modifier' of the capacity of power projection (Ripsman et al., 2016: 40), the salience of the post-Soviet space 'as such' to Russia is a very

\footnotetext{
${ }^{25}$ The record of Russia's behaviour regarding alliances in not entirely linear. Historically, Russia has perceived alliances as a key security threat (Tsygankov, 2018), and actions committed by other regional powers have revived such a perception after the end of Cold War.
} 
compelling argument. Countries belonging to the PSS - as stated in the third section - have both material and symbolic elements of salience: they are a sign of past greatness; can play a role as a buffer zone; have economic/energy importance; and are inhabited by Russian speaking people. If we take into account Paul Hensel's list of factors that determine the salience of a land dispute between two states, we find that they are all present in the case of Russian interventions in the PSS. Hensel states that the salience of a territorial ${ }^{26}$ dispute is determined by six elements (Hensel et al., 2008: 130):

(1) Territory is considered a homeland territory;

(2) Territory is inhabited by a permanent population;

(3) Territory previously belonged to the claimant state;

(4) Territory may contain important natural resources;

(5) Territory has an important economic or a strategic position; and

(6) Groups living on the territory have some sort of an ethnic/cultural relationship with the claimant state.

At first glance, it is evident that all conditions but the first are present in the relations among Russia and its near abroad. ${ }^{27}$ Consequently, it is not surprising to find that the PSS variable plays such a crucial role in Moscow's decision to escalate the level of a dispute.

The reactions of a state to international stimuli are affected/mediated by domestic factors. Accordingly, we now have to consider the impact of the two domestic variables that we have selected from the broad literature on Russia's foreign policy, to test their impact on military behaviour.

The first factor, the level of democracy/autocracy, was tested in two different ways: first, we analysed the impact of the change in Russia's level of democracy/autocracy on its military behaviour, not considering the nature of the opponent state's political regime (hypothesis 4a). In this case, the idea that an increase in the level of Russian authoritarianism (Pol1) increases the conflict-proneness of Moscow is consistent with the empirical result. An increase in the level of autocracy (or a decrease in the level of democracy) increases the probability of Russia's MID involvement from a $p_{\mathrm{u}}$ of 0.023 to a $p_{\mathrm{c}}$ of 0.037 . An authoritarian Russia is 1.5 times more likely to be involved in a military dispute with another state (the latter's political regime notwithstanding). These data are statistically significant ( $Z$ score: $3.38, p<0.001)$.

More controversial are the data regarding our test of the hypothesis derived from the democratic peace theory (hypothesis $4 \mathrm{~b}$ ). In this case, Moscow's military behaviour seems to contradict the dominant literature that affirms that democratic dyads are less conflict-prone than nondemocratic or mixed dyads. In the case of Russia, the probability of conflict is higher in the case of democratic or mixed dyads and lower when non-democratic dyads are considered (Pol2) ${ }^{28}$ Although the data about democratic and non-democratic dyads have no statistical significance, the finding is interesting because it highlights that the theory of 'democratic contagion' is more consistent with Russia's international behaviour than democratic peace theory: democratic spill over endangers regime survival; thus, Russia is more likely to target democratic states than non-democratic states (Ambrosio, 2009). ${ }^{29}$ This happens because Russia has an interest in

\footnotetext{
${ }^{26} \mathrm{Hensel}$ differentiates between factors affecting the salience level of territorial issues and factors affecting the salience level of maritime and river issues.

${ }^{27}$ However, some specifications are needed. Russia's intervention in Ukraine in 2014 (which is not considered in our data analysis) has often been analysed as a response to a challenge to Russia's status as a great power. In particular, Ukraine (and the ancient Kievian Rus') is widely regarded as the birthplace of modern Russian statehood. B. Barkanov, 'How Putin's Domestic Audience Explains Russia’s Behavior', Washington Post, 13 March 2014.

${ }^{28}$ The Polity IV database excludes approximately 500 cases and this omission can affect statistical results.

${ }^{29}$ Of the 48 MIDs in mixed dyads, only six involve Russia as a democratic state. The other 42 cases involve an authoritarian Russia against a democratic state. This fact strengthens the 'democratic contagion' hypothesis.
} 
Table 2. Logit model: Russia's military escalation decisions, 1992-2010

\begin{tabular}{lrrrrr}
\hline & \multicolumn{1}{c}{$B$} & \multicolumn{1}{c}{ SE } & Z score & Sig. & Exp $(B)$ \\
\hline$R P$ & -1.018 & 0.160 & -6.362 & $0.000^{\star \star \star}$ & 0.361 \\
All & 0.634 & 0.326 & 1.943 & 0.052 & 1.890 \\
PSS & 2.571 & 0.359 & 7.168 & $0.000^{\star \star \star}$ & 13.079 \\
Pol1 & -0.423 & 0.229 & -1.848 & 0.065 & 0.655 \\
Pol2 & 0.790 & 0.258 & 3.066 & $0.002^{\star \star}$ & 2.204 \\
$R V$ & 0.773 & 0.228 & 3.387 & $0.0007^{\star \star \star}$ & 2.166 \\
Intercept & -4.362 & 1.008 & -4.361 & $0.000^{\star \star \star}$ & 0.012 \\
\hline
\end{tabular}

${ }^{\star} P<0.05 ;{ }^{\star \star} P<0.01 ;{ }^{\star \star \star} P<0.001$ (two-tailed test).

actively resisting or undermining regional democratic promotion that may spill beyond the Russian borders. During the waves of colour revolutions across the post-Soviet space between 2005 and 2008, Russia officially condemned them as a 'regime overthrown' promoted by the West, and the Kremlin adopted several tools to achieve authoritarian resistance to such social change (Ambrosio, 2009). At the same time, Russia bolstered autocratic regimes in several post-Soviet states (Vanderhill, 2013) and promoted a global agenda parallel to that of the West (Bader et al., 2010; Dias and Freire, 2019).

The last domestic variable tested focuses on regime stability. Studies on Russia's foreign policy have produced contradictory evidence on this point. As we have seen in section two, some studies stress the depressing impact of regime instability on international behaviour (low profile foreign policy hypothesis - hypothesis 5a), while others stress evidence of more assertive foreign policy deriving from domestic instability (diversionary war hypothesis - hypothesis $5 b$ ).

Empirical data on regime vulnerability $(R V)$ clearly show that the diversionary hypothesis is more robust in the case of Russia. An intensification of regime instability increases the probability of Russia's MID involvement from 0.023 to 0.040 . Conversely, a rise in regime stability decreases the risk of military involvement from 0.023 to 0.009 : when Russia's regime is stable, the likelihood of MID involvement is 2.5 times lower. The data on high and low RVs are all statistically significant.

The bivariate analysis clearly shows that relative power $(R P)$ plays a decisive role in explaining the likelihood of Russia's MID involvement. A similar crucial role is played by the nature of the bone of contention: when a dispute involves a former Soviet state (PSS), the risk of a conflict with Moscow rises dramatically. Both the level of autocracy (Pol1) and domestic instability positively affect Russia's military behaviour, prompting a more aggressive posture. The democratic nature of target states (Pol2) does not seem to restrain Moscow's military behaviour: anxious about a possible democratic contagion, Moscow seems more prone to quarrel with democratic states.

Now, we shift to a multivariate analysis, where all the variables are considered jointly. Due to missing data on the level of democracy in countries below 500,000 inhabitants and in countries under foreign occupation, the multivariate analysis (logistic regression) was applied to a sample of 3048 dyads and 80 MIDs. ${ }^{30}$ The results are presented in Table 2.

The impact of relative power is confirmed for both direction and weight. Even when all the variables are considered as acting jointly, the power difference between Russia and the target states remains critical for explaining military escalation decisions. An increase in the power difference (a shift from a small power difference to a large power difference) reduces the probability

\footnotetext{
${ }^{30}$ For the logistic regression, independent variables have been coded in the following way: high 3, medium 2, low 1; dichotomous variables as yes 1 , no 0 ; democratic dyads 3 , mixed dyads 2 , non-democratic dyads 1 .
} 
of Russia MID involvement in a significant way. More to the point, a large $R P$ difference reduces the likelihood of a military escalation by $64 \% .{ }^{31} R P$ 's impact is highly statistically significant $(p<0.001)$. When compared to the bivariate results, these data demonstrate the important effect of domestic variables on the $R P$ role in Russia's military behaviour. When all the factors are not considered jointly, the shift from a small to a large $R P$ gap reduces the likelihood of MID involvement by approximately $35 \%$. These results are consistent with the neoclassical realist approach, which affirms that to understand a country's reaction to international stimuli, we have to consider also the modifying role of unit-level variables. ${ }^{32}$ In this case, domestic variables mitigate in a significant way the most negative effect of power gap.

The multivariate analysis confirms the eccentric role played by the alliance variable $(A l l)$, which maintains a positive sign and a low statistical significance $(p<0.10)$. These data deserve further investigation to test which of the alternative explanations advanced in the bivariate analysis can shed some light on this apparently contradictory result (Moscow's indifference towards alliance defence pacts, selection bias, a 'teach a lesson' strategy).

The role of the territorial salience of the dispute is largely confirmed by our multivariate analysis. The logit coefficient for the PSS variable is positive, as expected, and statistically significant $(p<0.001)$. The involvement of Russia in the post-Soviet space remains one of the best predictors of conflictual behaviour. An increase in the logit coefficient dramatically increases the event modelled (Russia's MID involvement). A dispute with a state belonging to the near abroad increases the risk of military confrontation by $100[\operatorname{Exp}(B)-1]=1200 \%$. In this case, as is the case for $R P$, other factors significantly affect the impact of the variable under observation (PSS, when considered alone, produced a change of $291 \%$ ). Thus, $R P$ and unit-level variables seem to have an amplifying effect on the impact of territorial salience on Russia's dispute decisions.

By analysing the three domestic variables included in our model (Pol1, Pol2, and $R V$ ), the bivariate results are partially confirmed. Poll, although operating in the expected direction, is not very statistically significant $(p<0.10)$. Nevertheless, the hypothesis that in the case of Russia's military behaviour the 'democratic contagion' theory works better than democratic peace theory is confirmed. A shift from non-democratic dyads to democratic dyads (Pol2) increases the probability of Russia's MID involvement by $100[\operatorname{Exp}(B)-1]=120 \%$. These data are statistically significant $(p<0.01)$.

The last domestic variable analysed is regime vulnerability. Logistic regression produced data consistent with the diversionary hypothesis. The logit coefficient for $R V$ was positive, meaning that domestic instability makes the event modelled more likely. When Russia is experiencing regime vulnerability, the risk of MID involvement increases. In particular, when $R V$ is high, the risk that Russia will resort to an external military confrontation increases by $100[\operatorname{Exp}(B)-1]=116 \%$. $R V$ has a more amplifying effect when considered together with the other variables: in the bivariate analysis, the impact of a high $R V$ was to increase the probability of Russia's MID involvement by $74 \%$. This means that a diversionary logic cannot be considered a good explanation without reference to power balancing considerations. ${ }^{33}$

In conclusion, the multivariate analysis is consistent with the bivariate analysis, and this fact clearly hints at the robustness of our empirical results. Another factor that unmistakably emerges is that unit-level variables tend to significantly affect states' external behaviour, amplifying (overreaction) or mitigating (under-balancing) conflict-proneness, as expected by neoclassical realism (Snyder, 1991; Schweller, 2004). The empirical findings are summarized in Table 3.

\footnotetext{
${ }^{31} 100[\operatorname{Exp}(B)-1]=-64$.

${ }^{32}$ On neoclassical realism, see Rose (1998); Lobell et al. (2009); Ripsman et al. (2016); Toje and Kunz (2012); Schweller (2004); Rosa (2018).

${ }^{33}$ These data are consistent with the conclusion of Mclaughlin Mitchell and Prins (2004) that show that diversionary tactics operate only in situations of pre-existing rivalry (an opportunity-rich environment).
} 
Table 3. Probability of Russia's military escalation decisions

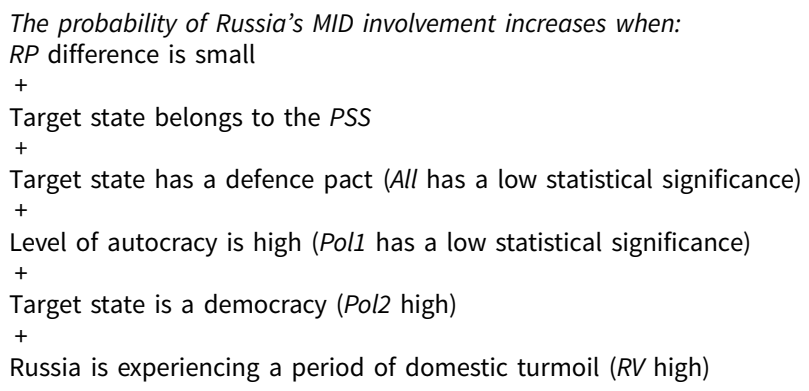

\section{Conclusion}

The purpose of this paper was to identify the best predictors of Russia's military behaviour between 1992 and 2010. To this aim, we have analysed all the MIDs in which Russia was involved according to the dataset from Correlates of War. Drawing on the literature on the quantitative analysis of conflict as well on Russia's foreign policy, we have identified five factors that may influence Moscow's military behaviour: Russia's relative power $(R P)$, the presence or not of an external ally supporting the disputant state $(A l l)$, the territorial salience of the disputed issue (whether it belongs to the post-Soviet space - PSS), the level of democracy/autocracy of the Russian regime $(\mathrm{Pol})$, and its regime vulnerability $(\mathrm{RV})$.

The importance of relative power $(R P)$ in accounting for Russia's MIDs involvement implies that Russia's military behaviour is mostly a function of external threats, as posed by realist theories. However, the fact that Russia's large power preponderance on the target state decreases its involvement in MIDs does not support the offensive realist argument; it is more in line with defensive realism. Overall, the results on relative power are consistent with previous studies on causes of war according to which power preponderance is more conducive to peace than the lack of it (Bremer, 1992; Kugler and Lemke, 1996).

Territorial salience of the post-Soviet space (PSS) has been found to increase significantly the likelihood of Russia's involvement in MIDs. Whether this happens because Russia finds easier to project its power onto neighbouring states thanks to the presence of former Soviet military infrastructure; or whether because Russia claims to have a legitimate position as hegemon deriving by its ethnical and historical connections in the region, is unclear. Interestingly, Russia's ambiguous official discourse on the PSS contributes on such unclarity: on the one hand, Russia frames the PSS according to a security and economic-oriented narrative - for example, the Collective Security Treaty Organization, the Shanghai Cooperation Organization, the Eurasian Economic Union - on the other hand, Russia legitimizes its presence in the PSS by underlying the importance of the region for Russian national identity - for example, Russkiy Mir (Russian World), Eurasian civilization, etc.

The presence of alliance for target states $(\mathrm{All})$ has not a strong effect on Russia's MIDs involvement as the previous variables. On the contrary, Russia's likelihood of MIDs involvement is greater with countries that do have a defence pact with a third country and not the other way around. Nevertheless, such results are not so definitive to claim that alliances - especially NATO - lose their deterrence effect on Russia's military behaviour. At the same time, Russia perceives the unipolar system and NATO enlargement as highly threatening ${ }^{34}$; consequently, it attempts to counterbalance it. Moreover, several studies have stressed to what extent the presence of NATO at Russia's border has not only exacerbated Russia relations with Western powers but

\footnotetext{
${ }^{34}$ Vladimir Putin, 'Speech and the Following Discussion at the Munich Conference on Security Policy', President of Russia, 2007 (http://en.kremlin.ru/events/president/transcripts/24034).
} 
also escalated rather than deterred militarized disputes between the post-Soviet states and Russia in the last twenty years (Mearsheimer, 2014).

At the domestic level, both the autocratic regime of Russia (Poll) and the democratic nature of target states (Pol2) affect Russia's military behaviour. An authoritarian Russia has been more inclined in MIDs involvement, and the democratic nature of target states has not restrained Moscow's military behaviour. Although the effect of regime type is not as strong as others considered here, Russia's has often had the suspicion that 'democracy promotion' masks the West's geopolitical interests and ambitions (Lukin, 2016). In order to contrast that, Russia gangs up with compatible authoritarian regimes (especially China), that acts as a new coalition for antidemocratic promotion (Ambrosio, 2008; Tolstrup, 2015).

Finally, regime vulnerability $(R V)$ has shown to positively influence Russia's MIDs involvement. Although some studies have stressed the depressing impact of regime instability on Russia's international behaviour by depicting Russia as a weak isolationist power too busy with internal weaknesses and threats to truly undermine the world order, this analysis clearly shows that the diversionary hypothesis is more robust in the case of Russia: the fear of regime (in-) security makes Russia more inclined to be involved in an MID (Balzer, 2015; Hale, 2018).

The main empirical findings of this research provide consistent arguments for the application of integrated theoretical models - such as neoclassical realism - that include both systemic and unit-level variables to address the sources of states' external behaviours (Rose, 1998; Wivel, 2005, 2017; Eun, 2012).

Funding. This research received no grants from public, commercial, or non-profit funding agency.

Data. The replication dataset is available at https://dataverse.harvard.edu/dataverse/ipsr-risp.

\section{References}

Ambrosio T (2008) Catching the 'Shanghai Spirit': how the shanghai cooperation organization promotes authoritarian norms in Central Asia. Europe-Asia Studies 60, 1321-1344.

Ambrosio T (2009) Authoritarian Backlash: Russian Resistance to Democratization in the Former Soviet Union. London: Routledge.

Asmus RD (2009) A Little War That Shook the World: Georgia, Russia, and the Future of the West. New York: St Martin's Press.

Bader J, Grävingholt J and Kästner A (2010) Would autocracies promote autocracy? A political economy perspective on regime-type export in regional neighbourhoods. Contemporary Politics 16, 81-100.

Balzer H (2015) The Ukraine invasion and public opinion. Georgetown Journal of International Affairs 16, 79-93.

Blainey G (1988) The Causes of War. New York: The Free Press.

Bremer S (1992) Dangerous dyads: conditions affecting the likelihood of interstate war, 1816-1965. Journal of Conflict Resolution 36, 309-341.

Bukkvoll T (2016) Why Putin went to war: ideology, interests and decision-making in the Russian use of force in Crimea and Donbas. Contemporary Politics 22, 267-282.

Casula P (2014) Russia's and Europe's borderlands. Problems of Post-Communism 61, 6-17.

Casula P (2015) The Syrian conflict through Russian eyes revisited. Russian Analytical Digest 175, 6-10.

Charap S and Welt C (2015) Making sense of Russian foreign policy: guest editors introduction. Problems of Post-Communism 62, 67-70.

Clunan AL (2018) Russia and the liberal world order. Ethics \& International Affairs 32, 45-59.

Cohen A (2007) Domestic factors driving Russia's foreign policy. The Heritage Foundation. Available at https://www.heritage. org/europe/report/domestic-factors-driving-russias-foreign-policy.

Costa Buranelli F (2017) Spheres of influence as negotiated hegemony - the case of Central Asia. Geopolitics 23, 378-403.

DeRouen K (1995) The indirect link: politics, the economy and the use of force. Journal of Conflict Resolution 39, 671-695.

Deyermond R (2016) The uses of sovereignty in twenty-first century Russian foreign policy. Europe-Asia Studies 68, 957 984.

Dias VA and Freire and MR (2019) Russia and the Arab spring: a counter-revolutionary power in the MENA region. In Çakmak C and Özçelik AO (eds), The World Community and the Arab Spring. Basingstoke: Palgrave Macmillan.

Diehl P (1991) Geography and war: a review and assessment of the empirical literature. International Interactions 17, 11-27.

Donaldson RH (2000) Boris Yeltsin's foreign policy legacy. Tulsa Journal of Comparative and International Law 7, $285-326$. 
Donaldson RH, Nogee JL and Nadkarni V (2014) The Foreign Policy of Russia: Changing Systems, Enduring Interests. Armonk: M.E. Sharpe.

Eun YS (2012) Why and how should we go for a multicausal analysis in the study of foreign policy? (Meta-)Theoretical rationales and methodological rules. Review of International Studies 38, 763-783.

Fearon JD (1995) Rationalist explanations for war. International Organization 49, 379-414.

Filippov M (2009) Diversionary role of the Georgia-Russia conflict: international constraints and domestic appeal. Europe-Asia Studies 61, 1825-1847.

Fordham B and Poast P (2016) All alliances are multilateral: rethinking alliance formation. Journal of Conflict Resolution $\mathbf{6 0}$, 840-865.

Forsberg T (2014) Status conflicts between Russia and the West: perceptions and emotional biases. Communist and Post-Communist Studies 47, 323-331.

Forsberg T and Haukkala and H (2018) The European Union. In Tsygankov A (ed.), Routledge Handbook of Russian Foreign Policy. London: Routledge.

Fravel MT (2007/2008) Power shifts and escalation: explaining China's use of force in territorial disputes. International Security 32, 44-83.

Frederick BA, Hensel PR and Macaulay C (2017) The issue correlates of war territorial claims data, 1816-2011. Journal of Peace Research 54, 99-108.

Freire MR and Kanet RE (2012) Russia and its Near Neighbours. Basingstoke: Palgrave Macmillan.

Gabuev A (2018) Russia's policy towards China: key players and the decision-making process. In Rozman G and Radchenko S (eds), International Relations and Asia's Northern Tier: Sino-Russia Relations, North Korea, and Mongolia. Basingstoke: Palgrave Macmillan.

Galeotti M and Bowen AS (2014) Putin's empire of the mind. Foreign Policy. Available at https://foreignpolicy.com/2014/04/ 21/putins-empire-of-the-mind/.

Gartzke EA and Poast and P (2018) Empirically assessing the bargaining theory of war: potential and challenges. In Thompson WR (ed.), The Oxford Encyclopedia of Empirical International Relations Theory. New York: Oxford University Press.

Gel'man V (2015) Authoritarian Russia: Analyzing Post-Soviet Regime Changes. Pittsburgh, PA: University of Pittsburgh Press.

Gibler DM (2009) International Military Alliances, 1648-2008. Washington: CQ Press.

Götz E (2016a) Putin, the state, and war: the causes of Russia's near abroad assertion revisited. International Studies Review 19, 228-253.

Götz E (2016b) Neorealism and Russia’s Ukraine policy, 1991-present. Contemporary Politics 22, 301-323.

Götz E (2017) Enemy at the gates: a neoclassical realist explanation of Russia's Baltic policy. Foreign Policy Analysis 15, 99-117.

Götz E and Merlen CR (2018) Russia and the question of world order. European Politics and Society 20, 133-153.

Hagan JD (1993) Political Opposition and Foreign Policy in Comparative Perspective. Boulder, CO: Lynne Rienner Publishers.

Hale HE (2018) How Crimea pays: media, rallying 'round the flag, and authoritarian support. Comparative Politics 50, 369-391.

Hensel P (2012) Territory: geography, contentious issues, and world politics. In Vasquez JA (ed.), What do We Know about War, 2nd Edn. Lanham: Rowman and Littlefield.

Hensel PR, McLaughlin Mitchell S, Sowers TE and Thyne CL (2008) Bones of contention: comparing territorial, maritime, and river issues. Journal of Conflict Resolution 52, 117-143.

Hill F and Gaddy CG (2015) Mr. Putin: Operative in the Kremlin. Washington, DC: Brookings Institution Press.

Hopf T (2002) Social Construction of Foreign Policy: Identities and Foreign Policies, Moscow, 1955 and 1999. Ithaca: Cornell University Press.

Huth PK (1996) Enduring rivalries and territorial disputes, 1950-1990. Conflict Management and Peace Science 15, 7-41. Jervis R (2013) Do leaders matter and how would we know? Security Studies 22, 153-179.

Johnson D (2015) Russia's approach to conflict: implications for NATO's deterrence and defence. NATO Research Paper, 111.

Jones DM, Bremer SA and Singer JD (1996) Militarized interstate disputes, 1816-1992: rationale, coding rules, and empirical patterns. Conflict Management and Peace Science 15, 163-212.

Jonsson O and Seely R (2015) Russian full-spectrum conflict: an appraisal after Ukraine. The Journal of Slavic Military Studies 28, 1-22.

Kanet RE (2018) Russia and global governance: the challenge to the existing liberal order. International Politics 55, 177-188.

Kenwick MR, Vasquez JA and Powers MA (2015) Do alliances really deter? The Journal of Politics 77, $943-954$.

Kim HM, Jungmoo W and Jae CL (2019) What is the relationship between alliance and militarized conflict? Analysis of reciprocal causation. Armed Forces \& Society (first published online 28 January).

Kuchins A and Zevelev and I (2012) Russia's contested national identity and foreign policy. In Nau HR and Ollapally D (eds), Worldviews of Aspiring Powers: Domestic Foreign Policy Debates in China, India, Iran, Japan and Russia. Oxford: Oxford Scholarship Online.

Kugler J and Lemke D (eds) (1996) Parity and War: Evaluations and Extensions of the War Ledger. Ann Arbor: University of Michigan Press. 
Kuhrt N (2018) Asia-Pacific and China. In Tsygankov A (ed.), Routledge Handbook of Russian Foreign Policy. London: Routledge.

Kuzio T and D'Anieri P (2018) The sources of Russia's great power politics: Ukraine and the challenge to the European order. E-international relations publishing. Available at https://www.e-ir.info/publication/the-sources-of-russias-greatpower-politics-ukraine-and-the-challenge-to-the-european-order/.

Larson DW and Shevchenko A (2010) Status seekers: Chinese and Russian responses to U.S. primacy. International Security 34, 63-95.

Larson DW and Shevchenko A (2014) Russia says no: power, status, and emotions in foreign policy. Communist and Post-Communist Studies 47, 269-279.

Laruelle M (2015) The Russian world: Russia's soft power and geopolitical imagination. Center on Global Interests, May 1-29.

Leeds BA (2003) Do alliances deter aggression? The influence of military alliances on the initiation of militarized interstate disputes. American Journal of Political Science 47, 427-439.

Levy J (2001) The diversionary theory of war: a critique. In Midlarsky M (ed.), Handbook of War Studies. London: Routledge.

Light M and Cadier D (2015) Russia's Foreign Policy: Ideas, Domestic Politics and External Relations. Basingstoke: Palgrave Macmillan.

Lo B (2015) Russia and the New World Disorder. Washington, DC/London: Brookings Inst. Press/Chatham House.

Lobell SE, Ripsman NM and Taliaferro JW (eds) (2009) Neoclassical Realism, the State, and Foreign Policy. Cambridge: Cambridge University Press.

Lukin A (2016) Russia in a post-bipolar world. Survival 58, 91-112.

Lynch AC (2011) Vladimir Putin and Russian Statecraft. Washington, D.C.: Potomac Books.

Malcolm N, Pravda A, Allison R and Light M (1996) Internal Factors in Russian Foreign Policy. Oxford: Royal Institute of International Affairs.

Mansfield ED and Snyder and J (1996) Democratization and the danger of war. In Brown M, Lynn-Jones S and Miller S (eds), Debating the Democratic Peace. Cambridge, Mass.: The MIT Press.

Maoz Z and Russett B (1993) Normative and structural causes of democratic peace. American Political Science Review 87, 624-638.

McFaul M (1997/98) A precarious peace: domestic politics in the making of Russian foreign policy. International Security 22, 5-35.

Mclaughlin Mitchell S and Prins BC (2004) Rivalry and diversionary uses of force. The Journal of Conflict Resolution 48, 937-961.

McLaughlin Mitchell S and Vasquez J (eds) (2014) Conflict, War, and Peace: An Introduction to Scientific Research. London: Sage/CQ Press.

Mearsheimer J (2014) Why the Ukraine crisis is the west's fault. Foreign Affairs 93, 77-89.

Morin JF and Paquin J (2018) Foreign Policy Analysis - A Toolbox. Basingstoke: Palgrave Macmillan.

Mouritzen H and Wivel A (2012) Explaining Foreign Policy: International Diplomacy and the Russo-Georgian War. Boulder, Colo: Lynne Rienner Publishers.

Neumann I (1995) Russia and the Idea of Europe: A Study in Identity and International Relations. London: Routledge.

Odinius D and Kuntz P (2015) The limits of authoritarian solidarity: the gulf monarchies and preserving authoritarian rule during the Arab spring. European Journal of Political Research 54, 639-654.

Ofitserov-Belskiy D and Sushenstov A (2018) Central and Eastern Europe. In Tsygankov A (ed.), Routledge Handbook of Russian Foreign Policy. London: Routledge.

Oldberg I (2007) Russia's great power ambitions and policy under Putin. In Kanet RE (ed.), Russia Re-Emerging Great Power. Basingstoke: Palgrave Macmillan.

Oneal JR and Russett B (1999) The Kantian peace: the pacific benefits of democracy, interdependence, and international organization. World Politics 52, 1-37.

Ortmann S (2018) Beyond spheres of influence: the myth of the state and Russia's seductive power in Kyrgyzstan. Geopolitics 23, 404-435.

Poast P (2019) Arguing about Alliances: The Art of Agreement in Military-Pact Negotiations. Ithaca: Cornell University Press.

Quackenbush S and Rudy M (2009) Evaluating the monadic democratic peace. Conflict Management and Peace Science 26, 268-285.

Rasler K and Thompson and WR (2012) Systemic theories of conflict. In McLaughlin Mitchell S, Diehl P, and Morrow JD (eds), Guide to the Scientific Study of International Processes. Oxford: Wiley-Blackwell.

Reed W (2000) A unified statistical model of conflict onset and escalation. American Journal of Political Science 44, 84-93.

Ripsman NM, Taliaferro JW and Lobell SE (2016) Neoclassical Realist Theory of International Politics. New York: Oxford University Press.

Roberts K (2018) The United States. In Tsygankov A (ed.), Routledge Handbook of Russian Foreign Policy. London: Routledge.

Rosa P (2018) Neoclassical Realism and the Underdevelopment of China's Nuclear Doctrine. Basingstoke: Palgrave Macmillan. 
Rosa P, Benati S, Foradori P and Longoni GM (2020) Neoclassical realism and Italy's military behaviour, 1946-2010: a combined dyad/nation analysis. Political Research Exchange 2, 1-21.

Rosato S (2003) The flawed logic of democratic peace theory. The American Political Science Review 97, 585-602.

Rose G (1998) Neoclassical realism and theories of foreign policy. World Politics 51, 144-172.

Roxburgh A (2013) The Strongman: Vladimir Putin and the Struggle for Russia. London-New York: I.B.Tauris.

Russett B (1993) Grasping the Democratic Peace. Princeton: Princeton UP.

Rytövuori-Apunen H (2019) Power and Conflict in Russia's Borderlands: The Post-Soviet Geopolitics of Dispute Resolution. London-New York: Tauris.

Samokhvalov V (2018) Russia and its shared neighbourhoods: a comparative analysis of Russia-EU and Russia-China relations in the EU's Eastern neighbourhood and Central Asia. Contemporary Politics 24, 30-45.

Schweller R (2004) Unanswered threats. A neoclassical realist theory of underbalancing. International Security 29, 159-201.

Senese PD (2005) Territory, contiguity, and international conflict: assessing a new joint explanation. American Journal of Political Science 49, 769-779.

Shapovalova N and Zarembo Z (2011) Russia's Machiavellian support for democracy. FRIDE Policy Brief.

Sherr J (2013) Hard Diplomacy and Soft Coercion: Russia's Influence Abroad. Baltimore, Maryland: Chatham House.

Shevtsova L (2015) Forward to the past in Russia. Journal of Democracy 26, 22-36.

Siddi M (2018) The role of power in EU-Russia energy relations: the interplay between markets and geopolitics. Europe-Asia Studies 70, 1-20.

Smith H (2014) Russia as a great power: status inconsistency and the two Chechen wars. Communist and Post-Communist Studies 47, 355-363.

Smyth R (2014) The Putin factor: personalism, protest, and regime stability in Russia. Politics \& Policy 42, 567-592.

Snyder J (1991) Myths of Empire, Domestic Politics and International Ambition. Ithaca: Cornell University Press.

Toal G (2017) Near Abroad: Putin, the West and the Contest over Ukraine and the Caucasus. New York: Oxford University Press.

Toje A and Kunz B (eds) (2012) Neoclassical Realism in European Politics: Bringing Power Back in. Manchester: Manchester University Press.

Tolstrup J (2015) Black knights and elections in authoritarian regimes: why and how Russia supports authoritarian incumbents in post-soviet states. European Journal of Political Research 54, 673-690.

Treisman D (2012) The Return: Russia's Journey from Gorbachev to Medvedev. New York: The Free Press.

Trenin D (2009) Russia's spheres of interest, not influence. The Washington Quarterly 32, 3-22.

Tsygankov A (2013) Russia's Foreign Policy: Change and Continuity in National Identity. Lanham, MA: Rowman \& Littlefield.

Tsygankov A (2015) Vladimir Putin's last stand: the sources of Russia's Ukraine policy. Post-Soviet Affairs 31, $279-303$.

Tsygankov A (2018) The sources of Russia's fear of NATO. Communist and Post-Communist Studies 51, 101-111.

Urnov M (2014) 'Greatpowerness' as the key element of Russian self-consciousness under erosion. Communist and Post-Communist Studies 47, 305-322.

Vanderhill R (2013) Promoting Authoritarianism Abroad. Boulder, CO: Lynne Rienner Publishers.

Vasquez JA (1995) Why do neighbors fight? Proximity, interaction, or territoriality. Journal of Peace Research 32, $277-293$.

Waltz K (1979) Theory of International Politics. Boston: McGraw-Hill.

White S and Feklyunina V (2014) Identities and Foreign Policies in Russia, Ukraine and Belarus - The Other Europes. Basingstoke: Palgrave Macmillan.

Wivel A (2005) Explaining why state X made a certain move last Tuesday: the promise and limitations of realist foreign policy analysis. Journal of International Relations and Development 8, 355-380.

Wivel A (2017) Realism in foreign policy analysis. Oxford Research Encyclopedia of Politics. Available at https://doi.org/10. 1093/acrefore/9780190228637.013.475.

Zürcher C (2007) The Post-Soviet Wars: Rebellion, Ethnic Conflict, and Nationhood in the Caucasus. New York: NYU Press.

Cite this article: Rosa P, Cuppuleri A (2021). Dangerous dyads in the post-Soviet space: explaining Russia's military escalation decisions, 1992-2010. Italian Political Science Review/Rivista Italiana di Scienza Politica 51, 355-372. https://doi.org/ 10.1017/ipo.2020.37 